\title{
The Effectiveness of Chronic Disease Management Program in Blood Pressure Control among Hypertensive Patients
}

\author{
Frieska Dyanneza',2), Didik Tamtomo3), Sugiarto4) \\ 1)Sebelas Maret University Hospital, Surakarta \\ 2)Masters Program in Public Health, Universitas Sebelas Maret \\ 3) Faculty of Medicine, Universitas Sebelas Maret \\ 4)Department of Internal Medicine, Dr. Moewardi Hospital, Surakarta
}

\begin{abstract}
Background: The prevention and management of hypertension are major public health challenges for Indonesia and the rest of the world. If the rise in blood pressure with age could be prevented or diminished, much of hypertension, cardiovascular and renal disease, and stroke might be prevented. In Indonesia, the Social Security Administration Agency (BPJS) has administered a government program to control chronic diseases, including hypertension, namely Prolanis (chronic disease management program). This study aimed to determine the effectiveness of chronic disease management program in controlling systolic blood pressure in hypertensive patients.
\end{abstract}

Subjects and Method: This was an analytic observational study with case control design. The study was conducted at Pratama Griya Husada Clinic 2 Tasikmadu, Karanganyar, Central Java, in April 2017. A sample of 120 hypertensive patients, consisting of 60 controlled hypertensive patients and 60 uncontrolled hypertension patients, were selected for this study using fixed disease sampling. The dependent variable was systolic blood pressure. The independent variable was chronic disease management program for systolic blood pressure control, consisting of health status monitoring, reminder, club activity, home visit, dietary education, and physical activity education. Data on diet were collected by Food Frequency Questionnaire (FFQ) based on the DASH eating plan. Physical activity data were collected by short-form International Physical Activity Questionnaire (IPAQ). The other data were collected using questionnaires. Multiple linear regression was used to analyze the data.

Results: Blood pressure of hypertensive patients was reduced by chronic disease management program, including monitoring health status $(\mathrm{b}=-6.34 ; 95 \% \mathrm{CI}=-12.42$ to $-0.26 ; \mathrm{p}=0.041)$, reminder $(b=-6.22 ; 95 \% \mathrm{CI}=-13.30$ to $-0.87 ; \mathrm{p}=0.085)$, club activity $(\mathrm{b}=-3.46 ; 95 \% \mathrm{CI}=-6.40$ to $-0.53 ; \mathrm{p}=0.021)$, home visit $(\mathrm{b}=-22.01 ; 95 \% \mathrm{CI}=-41.85$ to $-2.17 ; \mathrm{p}=0.030)$, dietary education $(\mathrm{b}=-$ $3.61 ; 95 \% \mathrm{CI}=-6.66$ to $-0.57 ; \mathrm{p}=0.020)$, and physical activity education $(\mathrm{b}=-0.40 ; 95 \% \mathrm{CI}=-0.79$ to $-0.01 ; \mathrm{p}=0.001$ ).

Conclusion: Chronic disease management program is effective to control blood pressure of hypertensive patients. The program's components including monitoring health status, reminder, club activity, home visit, dietary education, and physical activity education, are effective in reducing blood pressure in hypertensive patients.

Keywords: hypertension, chronic disease management program

\section{Correspondence:}

Frieska Dyanneza. Masters Program in Public Health, Universitas Sebelas Maret, Jl. Ir. Sutami 36 A, Surakarta, Central Java. Email: frieskadyanneza@yahoo.co.id. Mobile: +6285741667850.

\section{BACKGROUND}

Non-communicable disease is a chronic disease that cannot be spread from one person to another (Nur and Warganegara,
2016; Riskesdas, 2013). The non-communicable disease becomes the main factor for 63.00\% global mortality based on the global status report on non-communicable 
disease (Pusat Data dan Informasi Kementerian Kesehatan RI, 2012; Martiyana and Handayani, 2015).

WHO estimates that mortality due to the non-communicable disease will keep increasing throughout the world. By 2030, it is globally, regionally, and nationally estimated that there will be a transition of epidemiology from the communicable disease to the non-communicable disease and it is also estimated that the proportion of mortality rate will be $69.00 \%$ and the mortality rate itself will be 52 million people per year due to the non-communicable disease (Dinkes Jateng, 2014; Pusat Data dan Informasi Kesehatan RI, 2012).

The increasing rate of non-communicable disease has negative impact toward economy and productiveness. The noncommunicable impact has negative impact toward salary, participation and productiveness of labours, and working hours and also has negative contribution toward early retirement and defection including the permanent defection. The medication of noncommunicable disease demands long period and enormous fund; as a result, such medication disturbs the economy of both the patient and his or her family (Dinkes Jateng, 2014; Kreinsen et al., 2009).

The increase of non-communicable disease is related to the increase of risk factors due to the change of an individual's life style along with the development of the modern world, the population growth, and the increasing age of life expectation (Pusat Data dan Informasi Kementerian Kesehatan RI, 2012).

Hypertension is one of the non-communicable diseases. Hypertension becomes the main problem of public health in the world, including Indonesia, and becomes the third greatest cause of early mortality due to the ever-increasing prevalence. The prevalence of hypertension is estimated to be around one billion individuals or one of four adult individuals suffer from hypertension and hypertension itself becomes the cause of mortality for 7.1 million people per year or $13 \%$ of the total mortality throughout the world (Korneliani and Meida, 2012; Setiawan et al., 2013; Venkataraman et al., 2013).

Based on the data from WHO, there were around 600 million patients of hypertension all around the world in 2004 (Arifin et al., 2016). Then, there were $25.80 \%$ of hypertension patients in Indonesia in 2013. Hypertension still occupies the biggest proportion of disease in the Province of Central Java which is $57.89 \%$; as a consequence, this disease becomes the top priority of non-communicable disease control (Dinkes Jateng, 2014).

The number of hypertension patients in Karanganyar District is 12,329 people (Dinkes Karanganyar, 2014). This number is estimated to increase about $60.00 \%$ by 2025 (Diaz and Shimbo, 2013; Rustiani et al., 2014).

Around $13 \%$ of mortality due to hypertension is related to the cardiovascular disease, while $62 \%$ is related to the stroke (Geaney et al., 2015). The decreasing blood pressure influences the mortality rate due to the heart disease and the stroke. $5 \mathrm{mmHg}$ decreases on the diastolic blood pressure for five years consecutively is related to the decrease of stroke around $34 \%$ and to the decrease of coronary heart disease around $21 \%$. On the other hand, $7.5 \mathrm{mmHg}$ decreases on the diastolic blood pressure for five consecutive years is related to the decrease of stroke around $46 \%$ and to the decrease of coronary heart disease around 29\%. Furthermore, 10 $\mathrm{mmHg}$ decreases on the diastolic blood pressure is related to the decrease of stroke around $56.00 \%$ and to the decrease of 
Indonesian Journal of Medicine (2017), 2(1): 52-62

https://doi.org/10.26911/theijmed.2017.02.01.06

coronary heart disease around 37\% (Kokkinos et al., 2009).

The principle in medicating hypertension is preventing is better than medicating (Dinkes Jateng, 2014). The suggested first treatment for hypertension is changing the life style (Rustiani et al., 2014). The breakdown of hypertension starts prior to the diagnosis enforcement; however, through early detection and medication the impacts of hypertension can be decreased (Urgoji, 2014).

The government program in managing the chronic disease is known as Prolanis (Program Pengelolaan Penyakit Kronis or Chronic Disease Management Program). This program refers to the implementation of integrated health service system and proactive approach that involves participants, health facilities, and BPJS Kesehatan (Social Security Administration Agency). The aim of this program is to maintain the health of the participants who suffer from chronic disease in order that they achieve optimum life quality under effective and efficient cost of health service (Lumempouw et al., 2016). The activities of Prolanis consist of education, health status monitoring, club activities, reminder, and home visit (BPJS Kesehatan, 2014).

Based on the above background, this study therefore aims at analysing the influence of the Chronic Disease Management Program toward the systolic blood pressure of hypertension patients.

\section{SUBJECTS AND METHOD}

\section{Study design}

This was an analytic observational study with case control design. The study was conducted at Pratama Griya Husada Clinic 2 Tasikmadu, Karanganyar, on April 2017.

\section{Population and Sample}

The population in this study was the hypertension patients in Pratama Griya Husada
Clinic 2 Tasikmadu, Karanganyar. A sample of 120 hypertension patients was selected using fixed disease sampling.

\section{Study variables}

There were six variables in this study and these variables were divided into independent and dependent variables. The independent variables were health status monitoring, reminder, club activity, home visit, education on the eating pattern, and education on the physical activity. On the other hand, the dependent variable was the systolic blood pressure of the hypertension patients.

\section{Operational Definition of Variables}

Health status monitoring was defined as a routine monitoring toward the blood pressure in the health facility within the last three months. Reminder was defined as the activity of motivating the hypertension patients to perform routine visit to the health facility through the short message service that reminded the patients about the schedule of their visit. Club activity was defined as the gymnastic activity that had been performed in the health facility.

Furthermore, home visit was defined as the visitation toward the home of the hypertension patients for delivering health information. Education on the eating pattern was defined as the activity to improve the knowledge on the eating pattern using the behavioral results. Education on the physical activity was defined as the activity to improve the knowledge on the physical activity using the behavioral results. Last but not the least, the systolic blood pressure of the hypertension patients was defined as the systolic blood pressure that had been measured within the hypertension patients.

\section{Study Instrument}

The systolic blood pressure of the hypertension patients was measured by using sygmamometer and stethoscope. The pri- 
mary data that had been related to the health status monitoring, reminder, club activity, and home visit were gathered using a questionnaire.

Food Frequency Questionnaire (FFQ) based on DASH Eating Plan was distributed in order to gather the primary data that were related to the education on the eating pattern. Then, International Physical Activity Questionnaire (IPAQ) Short Form was distributed in order to gather the primary data that were related to the education on the physical activity.

The reliability test for the questionnaires had been conducted prior to their distribution. From the results of reliability test toward the education on the eating pattern, the researchers found that the total item correlation had been $\geq 0.20$ and the Alpha Cronbach had been $\geq 0.70$. As a result, all of the question items were considered reliable and might be applied as the guidelines in conducting the study.

\section{Data Analysis}

The univariate data analysis was conducted in order to display the characteristic data and the descriptive data of the variables within this study. The continuous data sample was described using $n$ parameter, mean, SD, minimum and maximum. On the other hand, the categorical data were described using $n$ parameter and percentage.

Then, the bivariate analysis was conducted in order to analyze the influence of the independent variables toward the dependent variable using Pearson Product Moment Correlation test. For the multivariate analysis, the researchers selected the multiple linear regression.

\section{RESULTS}

The characteristics of the subjects generally described their distribution. The characteristics of 120 subjects in this study were viewed based on the age and the gender.

Table 1 showed that from 120 subjects, $22.50 \%$ subjects were $41-50$ years old, $44.20 \%$ subjects were $51-60$ years old, and $33.30 \%$ subjects were 61-70 years old. $71.70 \%$ subjects were female, while the remaining $28.30 \%$ were male.

\section{Table 1. Study Subject Characteristics}

\begin{tabular}{llll}
\hline \multicolumn{1}{c}{ Characteristics } & \multicolumn{1}{c}{ Category } & N & \% \\
\hline Age & 41-50 years old & 27 & 22.50 \\
& 51-60 years old & 53 & 44.20 \\
\multirow{3}{*}{ Gender } & 61-70 years old & 40 & 33.30 \\
& Male & 34 & 28.30 \\
& Female & 86 & 71.70 \\
\hline
\end{tabular}

The results of the continuous data descriptive statistics in the form of systolic blood pressure, club activity, education on the eating pattern, and education on the physical activity could be seen in Table 2 . Table 2 showed that each variable had relatively small data variance. The mean value described the average score, while the standard deviation (SD) value described the data variance. The small SD value indicated that the data had been representative. The descriptive results of the categorical data in the form of health monitoring status, reminder, and home visit might be viewed in Table 3.

Table 3 showed that from 120 subjects, $75.80 \%$ subjects routinely performed health monitoring status while the remaining $24.20 \%$ did not routinely performed health status monitoring. 102 subjects did not receive reminder SMS (85.00\%) while 18 subjects received 
Indonesian Journal of Medicine (2017), 2(1): 52-62

https://doi.org/10.26911/theijmed.2017.02.01.06

reminder SMS (15.00\%). 98.30\% subjects

1.70\% did not attain home visit.

attained home visit while the remaining

Table 2. Univariate Analysis of the Variables

\begin{tabular}{lccccc}
\hline \multicolumn{1}{c}{ Variables } & n & Mean & SD & Min. & Max. \\
\hline Systolic Blood Pressure & 120 & 135.42 & 15.66 & 110 & 170.00 \\
Club Activity & 120 & 2.10 & 0.92 & 1 & 3.00 \\
Education on the Eating Pattern & 120 & 4.48 & 0.90 & 2.50 & 7.00 \\
Education on the Physical Activity & 120 & 21.99 & 6.71 & 12.60 & 43.20 \\
\hline
\end{tabular}

Table 3. Univariate analysis of the categorical data

\begin{tabular}{lcc}
\hline \multicolumn{1}{c}{ Variables } & $\mathbf{n}$ & \% \\
\hline Health Status Monitoring & & \\
1. Not Routine & 29 & 24.20 \\
2. Routine & 91 & 75.80 \\
Reminder & & \\
1. Not Receive Reminder SMS & 102 & 85.00 \\
2. Receive Reminder SMS & 18 & 15.00 \\
Home Visit & 118 & 98.30 \\
1. Not Attain Home Visit & 2 & 1.70 \\
2. Attain Home Visit & & \\
\hline
\end{tabular}

Table 4. Bivariate analysis on the influence of health status monitoring, reminder, club activity, education on the eating pattern, and education on the physical activity toward the systolic blood pressure of the hypertension patients

\begin{tabular}{lcc}
\hline \multicolumn{1}{c}{ Variables } & $\mathbf{r}$ & $\mathbf{p}$ \\
\hline Health Status Monitoring & -0.27 & 0.003 \\
Reminder & -0.16 & 0.079 \\
Club Activity & -0.30 & 0.001 \\
Home Visit & -0.13 & 0.161 \\
Education on the Eating Pattern & -0.32 & $<0.001$ \\
Education on the Physical Activity & -0.30 & 0.001 \\
\hline
\end{tabular}

From Table 4, the results of pearson product moment correlation test regarding the influence of health status monitoring toward the systolic blood pressure of the hypertension patients showed that $\mathrm{r}=-0.27$ with $\mathrm{p}=0.003$. This finding implied that there had been negative and statistically significant influence. The results of pearson product moment correlation regarding the influence of reminder toward the systolic blood pressure of the hypertension patients showed that $r=0.16$ and $p=0.079$. This finding implied that there had been negative and statistically insignificant influence.
The results of Pearson product moment correlation regarding the influence of club activity toward the systolic blood pressure of hypertension patients showed that $\mathrm{r}=-0.30$ with $\mathrm{p}=0.001$. This finding implied that there had been negative and statistically significant language. The results of Pearson product moment correlation regarding the influence of home visit toward the systolic blood pressure of the hypertension patients showed that $\mathrm{r}=-0.13$ with $\mathrm{p}=0.161$. This finding implied that there had been negative and statistically insignificant influence. 
The results of Pearson product moment correlation regarding the influence of education on the eating pattern toward the systolic blood pressure of the hypertension patients showed that $r=-0.32$ with $\mathrm{p}<$ 0.001. This finding implied that there had been negative and statistically significant influence. The results of Pearson product moment correlation regarding the influence of education on the physical activity toward the systolic blood pressure of the hypertension patients showed that $\mathrm{r}=$ 0.30 with $\mathrm{p}=0.001$. This finding showed that there had been negative and statistically insignificant language.

Table 5 showed the results of multiple linear regressions regarding the influence of health status monitoring, reminder, club activity, home visit, education on the eating pattern, and education on the physical activity toward the systolic blood pressure of the hypertension patients.

There had been statistically significant influence from the health status monitoring toward the systolic blood pressure of the hypertension patients. The the hypertension patients who routinely performed health status monitoring had $6 \mathrm{mmHg}$ lower systolic blood pressure in comparison to the hypertension patients who did not routinely perform health status monitoring $(\mathrm{b}=-6.34 ; 95 \% \mathrm{CI}=-12.42$ to $-0.26 ; \mathrm{p}=$ 0.041).

Table 5. Results of multiple linear regressions analysis

\begin{tabular}{lcccc}
\hline \multirow{2}{*}{ Independent Variables } & \multirow{2}{*}{ b } & \multicolumn{2}{c}{$\mathbf{9 5 \%}$ CI } & \multirow{2}{*}{$\mathbf{p}$} \\
\cline { 3 - 4 } & & Upper Limit & Lower Limit & $<1.19$ \\
Constant & -6.34 & -12.42 & 235.46 & -0.001 \\
Health Status Monitoring & -6.22 & -13.30 & -0.87 & 0.041 \\
Reminder & -3.46 & -6.40 & -0.53 & 0.085 \\
Club Activity & -22.01 & -41.85 & -2.17 & 0.021 \\
Home Visit & -3.61 & -6.66 & -0.57 & 0.020 \\
Education on the Eating Pattern & -0.40 & -0.79 & -0.01 & 0.046 \\
Education on the Physical Activity & & & & \\
$\mathrm{n}=120$ & & & & \\
$\mathrm{R}^{2}=23.3$ & & & \\
$\mathrm{p}<0.001$ & & &
\end{tabular}

There had been statistically significant influence from the club activity toward the systolic blood pressure of the hypertension patients. The hypertension patients who performed the club activity for 2-3 times in a month had $3 \mathrm{mmHg}$ lower systolic blood pressure in comparison to the hypertension patients who performed the club activity once in a month $(\mathrm{b}=-3.46$; 95\% CI= -6.40 to $-0.53 ; \mathrm{p}=0.021$ ).

There had been statistically significant influence from the home visit toward the systolic blood pressure of the hypertension patients. The hypertension patients who had home visit had $22 \mathrm{mmHg}$ lower systolic blood pressure than the hyper- tension patients who did not have the home visit $(b=-22.01 ; 95 \% \mathrm{CI}=-41.85$ to $-2.17 ; \mathrm{p}=$ 0.030).

There had been statistically significant influence from the education on the eating pattern toward the systolic blood pressure of the hypertension patients. The hypertension patients who had high DASH eating pattern had $4 \mathrm{mmHg}$ lower systolic blood pressure in comparison to the hypertension patients who had low DASH eating pattern $(b=-3.61 ; 95 \% \mathrm{CI}=-6.66$ to -0.57 ; $\mathrm{p}=0.020$ ).

There had been statistically significant influence from the education on the physical activity toward the systolic blood 
pressure of the hypertension patients. The hypertension patients who had high physiccal activity had $0.40 \mathrm{mmHg}$ lower systolic blood pressure in comparison to the hypertension patients who had low physical activity $(\mathrm{b}=-0.40 ; 95 \% \mathrm{CI}=-0.79$ to $-0.01 ; \mathrm{p}=$ 0.046).

$\mathrm{R}^{2}=23.30 \%$ implied that the six independent variables (health status monitoring, reminder, club activity, home visit, education on the eating pattern, and education on the physical activity) had been able to $23.30 \%$ explain the factors that influenced the systolic blood pressure of the hypertension patients and the remaining $86.70 \%$ explanation had been given by the factors outside the study.

\section{DISCUSSION}

\section{The influence of health status monitoring toward the blood pressure of the hypertension patients}

The results of the study showed that there had been negative and statistically significant influence from the health status monitoring toward the systolic blood pressure of the hypertension patients.

Hypertension is a chronic disease that demands routine medication. Hypertension patients demand routine and regular medical control in order to identify the condition of their blood pressure so that they are able to prevent complications or more severe diseases (Sulastri, 2015).

The misunderstanding that hypertension always has symptoms occur in most of the hypertension patients. The absence of any symptoms causes the hypertension patients to abandon the blood pressure examination. This might be dangerous because hypertension is a "silent killer" (WHO, 2013).

According to Sudirman (2011) in Sulastri (2015), if the blood pressure cannot be decreased within one month then the dose can be adjusted to the maximum level or the patients might add other type of medicines. There is a relationship between the history of medical control and the relapses and this relationship show that routine and regular control is important to prevent the occurrence of relapses.

Hypertension demands lifetime governance and routine medical control is very important in maintaining the blood pressure of hypertension patients under control (Harianto, 2014).

\section{The influence of reminder toward the blood pressure of the hyper- tension patients}

The results of the study showed that there had been negative and statistically insignificant influence from the reminder toward the systolic blood pressure of the hypertension patients.

One of the problems in the hypertension therapy is the patients' disobedience toward the pharmacology and nonpharmacology therapy. This disobedience is caused by several factors such as knowledge and communication between the patients and the medical staff (Alfian, 2014).

According to Fenerty et al. (2012) in Alfian (2014), the use of new technology is recommended in order to help improving health. Short message service might be benefitted in delivering messages of healthiness toward mobile phone owners.

The use of reminder short message service in order to increase obedience shows that the use of short message service is more innovative and has cost effectiveness. The use of reminder short message service application is easier in improving obedience within medication (Alfian, 2014).

The deliverance of short message as reminder and motivation for the hypertension patients provides positive influence toward behavior changes so that the hyper- 
tension patients improve their obedience and control toward the systolic and the diastolic blood pressure (Saputri et al., 2016).

This is in accordance with a study by Alfian (2014) who found that reminder short message service has positive influence toward significantly decreasing the blood pressure of the hypertension patients.

\section{The influence of club activity toward the blood pressure of the hypertension patients}

The results of this study showed that there had been negative and statistically significant influence from the club activity toward the systolic blood pressure of the hypertension patients.

Exercise is related to hypertension management because regular exercise can decrease periphery burden that will decrease the blood pressure (Anggara and Prayitno, 2013).

This is in accordance to a study by Lumampouw et al. (2016) who found that there is meaningful decrease on the systolic and diastolic blood pressure after performing prolanis exercises for four consecutive weeks.

According to Maryam (2008) in Werdani and Sawo (2015), regular exercises might respond in a response toward the cardiovascular namely the meaningful blood pressure decrease. From a study by Werdani and Sawo (2015), it was found that the significant blood pressure decrease starts to occur from the fourth week.

A study by Liu et al. (2012) in Werdani and Sawo (2015) proposed that there is permanent systolic and diastolic blood pressure decrease on the fifth week after the exercise and the blood pressure decrease has been apparent from the first until the third week. The integrated control toward the blood pressure will occur during the exercise. The blood pressure is control- led reflexively through the autonomous nerve system, especially through a special sensor known as baroreceptor reflex that serves as the control toward the acute change of the blood pressure. Programmed and continuous exercise might improve the cardiovascular functions through the space expansion on the atrium and the ventricle within the heart and through the improvement of blood vessel elasticity.

After 16 weeks of exercises with moderate intensity, there are $7 \mathrm{mmHg}$ decrease on the systolic blood pressure and $5 \mathrm{mmHg}$ decrease on the diastolic blood pressure in the hypertension patients. The hypertension patients who do not perform exercises within the same period has small increase on their blood pressure (Kokkinos, 2009).

\section{The influence of home visit toward the blood pressure of the hyper- tension patients}

The results of the study showed that there had been negative and statistically significant influence from the home visit toward the systolic blood pressure of the hypertension patients.

The study by Phillipus (2002) in Triasih et al. (2007) proposes that the clients who attain home visit by the medical staff are 2.15 times more obedient in taking their medicines.

The results of this study are in accordance with those of Utami et al. (2013) which conclude that the elders who attain more routine home visit perform blood pressure control in comparison to the elders who do not attain routine home visit and that there are different systolic and diastolic blood pressures between the elders who have attained home visit and the elders who have not attained home visit. 
Indonesian Journal of Medicine (2017), 2(1): 52-62

https://doi.org/10.26911/theijmed.2017.02.01.06

\section{The influence of education on the eating pattern toward the blood pressure of the hypertension patients}

The results of this study showed that there had been negative and statistically significant influence from the education on the eating pattern toward the systolic blood pressure of the hypertension patients.

The governance of hypertension is lifetime and, therefore, the obedience of hypertension patients in attending to the education given by the medical staff is important in order to maintain the blood pressure under control (Harianto, 2014).

Decreasing the blood pressure among the hypertension patients can be achieved by applying the healthy eating pattern based on the DASH (Dietary Approaches to Stop Hypertension) eating plan. DASH eating plan emphasizes the intake of salt, fruit, vegetables, grains, low-fat dairy products, and food (Huang, 2008).

According to Ropaloza et al. (2015), DASH eating plan can decrease $6 \mathrm{mmHg}$ systolic blood pressure and $3 \mathrm{mmHg}$ diastolic blood pressure.

The study by Amran et al. (2010) shows that the blood pressure decreases after the consumption of fruit has been added to the daily menu in the breakfast, in the lunch, and in the dinner for 7 days consecutively. In general, the blood pressure decreases around $7.67 \mathrm{mmHg}$, the lowest decrease of systolic blood pressure is $3 \mathrm{mmHg}$, and the highest decrease of systolic blood pressure is $13 \mathrm{mmHg}$. The addition of fruit consumption on the daily menu causes the increase of potassium intake. Potassium causes the decrease on the systolic and the diastolic blood pressure.

\section{The influence of education on the physical activity toward the blood pressure of the hypertension patients.}

The results of this study showed that there had been negative and statistically significant influence from the education on the physical activity toward the systolic blood pressure of the hypertension patients.

Hypertension can be controlled through the regular improvement of physical activity (Werdani and Sawo, 2015). A study by Malekzadeh et al. (2013) shows that the decrease on the hypertension prevalence can be found in the people with higher physical activity. The moderate physical activity that is performed regularly can decrease the systolic and the diastolic blood pressure for $10 \mathrm{mmHg}$ in $75 \%$ hypertension patients. The physical activity can be used as a choice of hypertension therapy for preventing complication.

A study by Gandasenta and Kusumaratna (2011) showed that the risk of hypertension occurrence within the group of high physical activity is 0.40 times lower than the risk of hypertension occurrence within the group of low physical activity. It is in accordance with the results of a prospective study which showed that there is an occurrence of hypertension decrease on 27,055 health women who perform regular physical activity (1,500 Kkal/week).

\section{REFERENCE}

Alfian R (2014). Layanan pesan singkat pengingat untuk meningkatkan kepatuhan dan menurunkan tekanan darah pasien hipertensi di RSUD Dr. H. Moch Ansari Saleh Banjarmasin. Media Farmasi 11(2).

Amran Y, Febrianti, Irawanti L (2010). Pengaruh tambahan asupan kalium dari diet terhadap penurunan hipertensi sistolik tingkat sedang pada 
lanjut usia. Jurnal Kesehatan Masyarakat Nasional 5(3).

Anggara FHD, Prayitno N (2013). Faktorfaktor yang berhubungan dengan tekanan darah di Puskesmas Telaga Murni, Cikarang Barat Tahun 2012. Jurnal Ilmiah Kesehatan 5(1).

Arifin MH, Weta IW, Ratnawati, NLKA (2016). Faktor-faktor yang berhubungan dengan Kejadian Hipertensi pada Kelompok Lanjut Usia di Wilayah Kerja UPT Puskesmas Petang I Kabupaten Badung Tahun 2016. EJurnal Medika 5(7).

BPJS Kesehatan (2014). Panduan Praktis PROLANIS (Program Pengelolaan Penyakit Kronis). Jakarta.

Diaz KM, Shimbo, D (2013). Physical Activity and the Prevention of Hypertension. Curr Hypertens Rep 15(6).

Dinkes Karanganyar (2014). Profil Kesehatan Kabupaten Karanganyar Tahun 2014. Karanganyar.

Dinkes Jateng (2014). Profil Kesehatan Provinsi Tahun 2014. Semarang.

Gandasentana RD, Kusumaratna RK (2011). Physical activity reduced hypertension in the elderly and costeffective. Universa Medicina 30(3).

Geaney F, Fitzgerald S, Harrington JM, Kelly C, Greiner BA, Perry IJ (2015). Nutrition Knowledge, Diet Quality and Hypertension in a Working Population. Preventive Medicine Reports.

Harianto F (2014). Tingkat kepatuhan pasien hipertensi terhadap edukasi penatalaksanaan hipertensi oleh petugas kesehatan Puskesmas Abang I, Kabupaten Karangasem Bali Periode Januari-Desember 2013. SM 6(1).

Huang $N$ (2008). Lifestyle management of hypertension. Australian Prescriber 31(6).

Kokkinos PF, Giannelou A, Manolis A, Pittaras A (2009). Physical Activity in
The Prevention and Management of High Blood Pressure. Hellenic Journal of Cardiology.

Korneliani K, Meida D (2012). Obesitas dan Stress dengan Kejadian Hipertensi. Jurnal Kesehatan Masyarakat 7(2). Kreinsen DS, Blumel M, Busse R (2009). Chronic Disease Management in Europe. Eurohealth 15(1).

Lumempouw DO, Wungouw HIS, Polii $\mathrm{H}$ (2016). Pengaruh Senam Prolanis terhadap Penyandang Hipertensi. Jurnal e-Biomedik (eBM) 4(1).

Malekzadeha MM, Kamangar F, Khademi H, Golozar A, Islami F, Pourshamsa A, Poustchi H, et al. (2013). Prevalence, awareness and risk factors of hypertension in a large cohort of Iranian adult population. Journal of Hypertension.

Martiyana C, Handayani L (2015). Perilaku pencarian pengobatan terhadap penyakit tidak menular di Desa Sulaho, Kecamatan Lasusua, Kabupaten Kolaka Utara. Buletin Penelitian Sistem Kesehatan. 18(4).

Pusat Data dan Informasi Kementerian Kesehatan RI (2012). Gambaran penyakit tidak menular di rumah sakit di Indonesia Tahun 2009 dan 2010. Buletin Jendela Data dan Informasi Kesehatan 2(2).

Riskesdas (2013). Riset Kesehatan Dasar. Jakarta: Badan Penelitian dan Pengembangan Kesehatan Kementerian Kesehatan RI.

Ropaloza, Garcellano M (2015). Nonpharmacologic Management of Hypertension: What Works?. American Family Physician 91(11).

Rustiani E, Andrajati R, Arsyanti L (2014). Analisis Penggunaan Obat Antihipertensi di Poliklinik Rawat Jalan Rumah Sakit PMI Bogor: Perbandingan Cost Effectiveness dan Kualitas Hidup 
Indonesian Journal of Medicine (2017), 2(1): 52-62

https://doi.org/10.26911/theijmed.2017.02.01.06

Pasien. Jurnal Ilmu Kefarmasian Indonesia 12(2).

Saputri ZG, Akrom, Darmawan E (2016). Counseling and Motivational Short Text Messages Increase Adherence and Behavioral Changes in Patient with Hypertension. Jurnal Kedokteran dan Kesehatan Indonesia 7(3).

Setiawan GW, Wungouw HIS, Pangemanan DHC (2013). Pengaruh Senam Bugar Lanjut Usia (Lansia) terhadap Kualitas Hidup Penderita Hipertensi. Jurnal e-Biomedik (eBM) 1(2).

Sulastri (2015). Hubungan anntara Stres dan Riwayat Konrol dengan Kekambuhan Hipertensi pada Lansia di UPTD PSLU Natar Lampung Selatan. Jurnal Kesehatan 6(2).

Triasih F, Istiawan R, Riyadi S (2007). Pengaruh kunjungan rumah oleh perawat terhadap tingkat kepatuhan pengobatan penderita pneumonia pada balita di Wilayah Kerja Puskesmas 2 Baturaden. Jurnal Keperawatan Soedirman 2(1).
Urgoji JU (2014). Developing a Lifestyle Modifcation Toolkit to Prevent and Manage Hypertension Among African American Women. Walden University ScholarWorks.

Utami PAS, Sahar J, Widyatuti (2013). Pengendalian faktor risiko hipertensi pada agregat lansia melalui kunjungan rumah. Jurnal Keperawatan Indonesia. 16(1).

Venkataraman R, Kumar S, Kumaraswamy M, Singh R, Pandey M, Tripathi P, Sarath (2013). Smoking, Alcohol and Hypertension. International Journal of Pharmacy and Pharmaceutical Sciences 5(4).

Wedani YDW, Sawo EB (2015). Pengaruh Senam Jantung terhadap Durasi Penurunan Tekanan Darah dan Nadi Istirahat pada Hipertensi Stadium I. Jurnal Ners Lentera 3(1).

WHO (2013). High blood pressure: The Silent killer stay healthy: Check your blood pressure. WHO Western Pasific Region. 